\title{
Implementasi TV Sekolah sebagai Media Pembelajaran di TK dalam Meningkatkan Kreativitas Guru
}

\author{
Fifi Italiana ${ }^{1}$, Sri Watini ${ }^{2}$ \\ 1,2Universitas Panca Sakti, Bekasi, Indonesia \\ E-mail:thompzoy2@gmail.com, srie.watini@gmail.com
}

\begin{tabular}{l}
\hline Article Info \\
\hline Article History \\
Received: 2022-02-03 \\
Revised: 2022-02-22 \\
Published: 2022-03-01 \\
\\
Keywords: \\
School TV; \\
Learning Media; \\
Teacher Creativity; \\
TK. \\
\\
\hline Artikel Info \\
Sejarah Artikel \\
Diterima: 2022-02-03 \\
Direvisi: 2022-02-22 \\
Dipublikasi: 2022-03-01
\end{tabular}

Kata kunci:

Tv Sekolah;

Media Pembelajaran;

Kreativitas Guru;

TK.

\begin{abstract}
The creativity of teachers becomes challenged when there is a period of pandami covid 19 that is present in the community that makes learning that is usually done in school into learning from home. Teachers are required to be able to teach remotely or commonly called distance learning (online learning system/ online learning). Teachers are required to provide more interesting learning media and make it easier for parents of students to better understand the learning that will be done at home in order to help their children in completing tasks that will be given by the teacher. With the presence of school TV makes teachers to be able to increase their creativity in planning, composing and realizing in the form of learning activities on school TV that can be accessed by learners.
\end{abstract} \begin{abstract}
Abstrak
Kreativitas guru menjadi tertantang ketika adanya masa pandami covid 19 yang hadir ditengah masyarakat yang menjadikan pembelajaran yang biasanya dilakukan disekolah menjadi belajar dari rumah. Guru diharuskan bisa mengajar dari jarak jauh atau biasa disebut pembelajaran jarak jauh (sistem online/ pembelajaran daring). Guru dituntut untuk memberikan media pembelajaran yang lebih menarik dan memudahkan orang tua siswa agar lebih memahami pembelajaran yang akan dilakukan dirumah agar dapat membantu putra- putri mereka dalam menyelesaikan tugas yang akan diberikan oleh guru. Dengan hadirnya TV sekolah menjadikan guru untuk dapat meningkatkan kreativitasnya dalam merencanakan, menyusun dan mewujudkan dalam bentuk tayangan kegiatan pembelajaran di TV sekolah yang dapat dijadikan media pembelajaran dan dapat akses oleh peserta didik terutama di TK.
\end{abstract}

\section{PENDAHULUAN}

Pada masa pandemi covid 19 ini banyak masyarakat yang ruang geraknya terpaksa harus dibatasi untuk bertemu atau berjumpa langsung dengan masyarakat lainnya dilingkungan sekitar mereka, tanpa terkecuali yang paling sangat terasa dari pembatasan ruang gerak selama pandami ini adalah dari pihak sekolah dimana yang tadinya anak-anak dapat berjumpa dengan teman- teman sebayanya, belajar dan bermain bersama disekolah diharuskan untuk dilakukan dirumah masing-masing, sehingga secara tidak langsung, guru dituntun untuk dapat mendesain sistem pembelajarannya yang awalnya dilakukan disekolah menjadi dikerjakan dirumah. Guru sebagai sosok pendidik bagi anak-anak di sekolah yang merupakan bagian yang menjadi pokok dalam pencapaian tujuan pendidikan, peran guru yang sangat strategis dalam pembelajaran tentunya harus dibarengi dengan kemampuan guru sebagai pendidik, mengapa guru harus siap sedia belajar mengajar dimana saja mereka berada, Kapan saja waktunya, bagaimana saja keadaan kondisi lingkungannya, dan apa saja yang dapat dijadikan media pem- belajaran merupakan salah satu tantangan terbesar sebagai guru dalam mengembangkan kreativitasnya, membangun kreativitas guru membutuhkan proses, ia tidaklah lahir tiba-tiba, ada proses yang mengawalinya seperti: (1) Belajar dari pengalaman mengajar, baik diperoleh dari pengalaman sendiri maupun dari pengalaman guru lain. Guru dapat belajar dan merefleksikan perjalanan proses belajar mengajarnya ke dalam praktik pembelajaran bersama peserta didik, (2) Rasa cinta dan kasih sayang yang mendalam terhadap muridmuridnya agar mereka men-jadi manusia ideal di masa yang akan datang. Cinta adalah energi kehidupan. Cinta merupa-kan sumber pemicu yang kuat atas lahirnya kreativitas, jika ada cinta dan kasih sayang, maka rasa dan jiwa guru terlibat dalam proses pengajaran dan pendidikannya sehingga to-talitas kinerja guru lahir. Perasaan siswa dapat menangkap cinta kasih gurunya sehingga terjalin hubungan psikologis antara peserta didik dan guru, (3) Adanya tanggung jawab yang mendalam terhadap tugasnya, (4) Guru giat belajar untuk meningkatkan kualitas pengetahuan, kepribadian 
dan keterampilan-nya yang berhubungan dengan tugas dan tanggung jawabnya sebagai guru.

Pada usia dini terdapat beberapa masa yang perlu diketahui oleh pendidik PAUD, yaitu masa peka, masa egosentris, masa meniru, masa berkelompok, masa bereksplorasi, dan masa pembangkang. PAUD dititikberatkan pada peletakan dasar ke arah pertumbuhan dan perkembangan seluruh kecerdasan yang meliputi 9 kecerdasan majemuk yaitu linguistik verbal, logika matematika, visualspasial, musikal, bodi kinestetik, naturalis, interpersonal, intrapersonal, dan spiritual, selain itu PAUD secara umum juga mengembangkan berbagai potensi anak sejak dini sebagai persiapan untuk hidup dan dapat menyesuaikan diri dengan lingkungannya. Semakin berkembangnya dunia pendidikan anak usia dini , semakin besar tuntutan untuk menjadi guru PAUD yang mampu menguasai dunia anak dan mampu berkreativitas dalam setiap kegiatan pembelajaran dan ketepatan dalam menyampaikan media pembelajarannya. Saat ini, guru PAUD di tuntut untuk dapat mengikuti perkembangan media pendidikan anak usia dini yang sesuai dengan masanya saat ini, yaitu masa kegiatan pembelajaran yang di berikan dengan cara online atau daring (dalam jaringan).

Arsyad (2015:10), Media pembelajaran adalah segala sesuatu yang dapat digunakan untuk menyampaikan informasi dalam proses belajar mengajar sehingga dapat merangsang perhatian dan minat siswa dalam belajar. Menurut Karim (2014:7), media pembelajaran adalah suatu perentara yang menghubungkan si penyampai pesan dengan si penerima pesan, dalam hal ini pesan berupa materi pembelajaran untuk mencapai suatu tujuan dalam hal yang berhubungan dengan program pendidikan. Media pembelajaran untuk anak usia dini itu luas, bukan hanya media yang sengaja dirancang dan di desain atas kreativitas guru saja akan tetapi benda apapun bisa dijadikan media pembelajaran selagi benda itu memiliki nilai edukasi, dalam pembuatan media pembelajaran ini menurut Mansur (2008:53) ada beberapa prinsip yang harus diperhatikan dalam pembuatan media yaitu media pembelajaran yang dibuat hendaknya dapat digunakan untuk mengembangkan berbagai aspek perkembangan anak dan dapat dijadikan sebagai media pembelajaran secara berulang. Siti maymunah, sri Watini,(2021) pemanfataan video pembelajaran dapat diterapkan pada masa pandemi dan dapat digunakan oleh anak-anak untuk menerima pembelajaran yang diberikan seperti tugas dengan materi pembelajaran yang sifatnya pembiasaan atau kegiatan yang menyenangkan yang dapat dilakukan dirumah. Hamalik (1986) yakni telah menunjukkan bahwa penggunaan media pengajaran dalam proses belajar mengajar dapat merangsang keinginan dan minat baru, merangsang dan merangsang kegiatan belajar dan bahkan dapat memiliki efek psikologis pada siswa.

Saat ini sudah terdapat TV sekolah yang dapat dijadikan media kreativitas guru dalam mengelola kegiatan pembelajaran, dengan ada-nya TV Sekolah kreativitas guru sangat membantu dalam menyiapkan dan menyusun rencana kegiatan apa yang akan di laksanakan di TV Sekolah sehingga kegiatan anak dapat disiarkan melalui TV sekolah. Keberadaan TV sekolah ini menjadikan guru bertambah kreatif untuk menyesuaikan dan mengisi acara TV Sekolah sesuia dengan tema tema kegiatan yang telah ditentukan sekolah, sehingga menjadi tayangan yang sangat menarik untuk Usia dini dan tentunya orangtua, dan kreativitas guru dalam menyiapkan dan menyusun kegiatan yang akan tayang di TV Sekolah menjadi penelitian yang menarik, kreativitas guru meningkat dalam mengembangkan TV sekolah. TV Sekolah berbeda dengan TV yang saat ini ada, TV ini khusus untuk kegiatan pembelajaran anak "TV sekolah Memiliki hak Cipta atas nama Sri watini, Dkk, dengan nomor pencatatan 000224874 yang diterbitkan pada tanggal 1 Juli 2020 di Jakarta", TV sekolah itu memiliki fitur utama yang bervariasi, panggung sekolah, perpustakaan digital, kelas virtual dan ekstra-kurikuler.

\section{METODE PENELITIAN}

Penelitian ini menggunakan kajiaan literatur, Menurut (Marzali, 2017) kajian Literatur adalah suatu pencarian kepustakaan dengan cara membaca berbagai sumber buku, jurnal dan terbitan terbitan lain yang berhubungan dengan topik penulisan, sehingga menciptakan suatu karya tulis. Studi pustaka ialah kata lain dari kajian pustakka, kajian teoritis, menurut (Melfianora, 2017), yang dimaksud kajian kepustakaan adalah pencarian dengan menggunakan karya tertulis yang diantaraanya hasil penelitian yang dipublikasikan maupun yang belum. Sumber data yang dibutuhkan dari kajian ini tidak harus kelapangan tetapi memanfaatkan sumber perpustakaan dalam memperoleh data, dari penjelasan di atas maka dapat diartikan kajian literatur adalah sebuah penulisan yang 
berasal dari penelusuran sumber jurnal, buku, seminar dan artikel, dengan tujuan untuk memperkenalkan kajian-kajian baru dalam topik tertentu. Menurut (Marzali, 2017) langkahlangkah dalam menulis kajian literatur adalah sebagai berikut: (1) Mulai mencari kata kunci, bahan materi dan referensi yang berhubungan dengan kajian artikel, (2) Membaca abstrak penelitian yang relevan yang dapat diperoleh dari berbagai sumber jurnal buku dan seminar, (3) Mencatat hasil bacaan dengan referensi bibliografi secara rinci, (4) Membuat kajian pustaka dan disusun secara tematis yang sesuai teori teori dan konsep konsep penting yang berhubungan dengan topik artikel, (5) Pada akhir kajian pustaka, menuliskan pandangan umum tentang topik yang di-lakukan.

Analisis ini menggunakan pengumpulan sumber data, reduksi data kemudian melakukan penarikan kesimpulan, untuk menganaalisis penulisan ditentukan kebaruan pustaka yang terkaait dengan topik penulisan.

1. Pengumpulan sumber data Penulisan.

Jurnal literature ini bersumber dari data jurnal-jurnal dan sumber internet

2. Reduksi data.

Setelah mendapatkan data, sumber data tersebut dianalisis untuk diambil materi yang relevan dan berkaitan dengan judul.

3. Penarikan Kesimpulan

Selanjutnya semua sumber data dirangkum secara rinci untuk diambil kesimpula.n

\section{HASIL DAN PEMBAHASAN}

Berdasarkan jurnal dari Ifat latifah,Sri Watini, (2022), Peran TV Sekolah sebagai alternative media pembelajaran jarak jauh (PJJ) TKIT Al Hikmah sudah mampu menjadikan TV Sekolah sebagai alternatif media pembelajaran yang dilakukan secara PJJ atau BDR, walaupun pemanfaatan TV Sekolah ini masih dilakukan selama sepekan sekali, tetapi hal ini sudah membuat alternative Media Pembelajaran yang lebih kreatif dan bervariasi serta sesuai dengan kondisi saat New Normal. Ini salah satu bukti bahwa TV Sekolah dapat menjadi media pembelajaran dalam meningkatkan kreativitas guru disekolah, peningkatan Kreativitas guru terlihat jelas saat akan diberlakukannya TV sekolah di suatu lembaga, terutama di lembaga PAUD, dalam Hal ini Guru sangat berperan aktif dalam menjalankan dan mengembangkan TV sekolah, hal ini terlihat dalam tahapan ketika kegiatan pembelajaran akan tayang di TV
Sekolah. Persiapan yang harus di kerjakan guru adalah:

1. Menyusun Rencana Pelaksanaan Pembelajaran Mingguan (RPPM).

2. Menyusun Rencana Pelaksanaan Pembelajaran Harian (RPPH), RPPH yang sudah di sesuaikan media pembelajaran yang akan di Gunakan.

3. Membuat beberapa Video berkolaborasi dengan teman sewajat, sehingga guru dapat membuat kegiatan pembelajaran yang sudah di dokumentasikan dalam bentuk portofolio video.

4. Membuat Video pembelajaran untuk kegiatan yang akan dan sedang berjalan dan siap di masukkan kedalam program TV Sekolah.

5. Mulai membuat kegiatan pembelajaran untuk TV Sekolah dan mempublish.

6. Guru menyudun waktu secara teratur sehingga Kegiatan dapat tayang di TV sekolah sesuai jadwal yang telah di rencanakan dalam RPPH.

Selanjutnya sekolah sudah dapat rutin mempublish kegiatan pembelajaran di chanel TV sekolah lebih menarik dan lebih bervariasi, sehingga anak anak tidak merasa jenuh dengan kegiatan Pembelajaran Jarak Jauh atau Belajar dari Rumah.

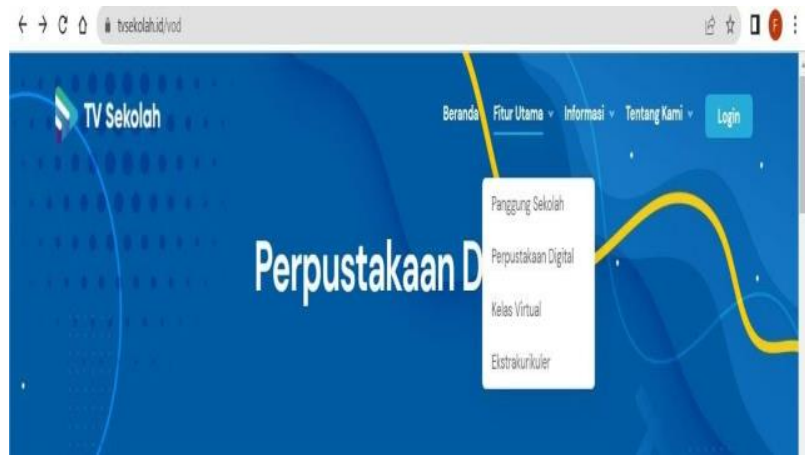

Gambar 1. Beranda TV Sekolah sebagai sarana pembelajaran daring
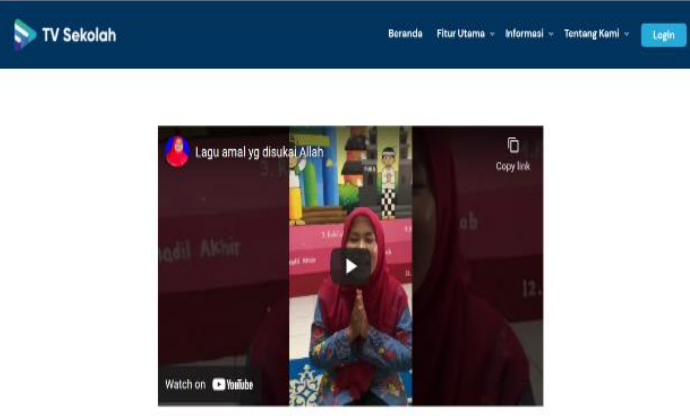

Lagu amal yang disukain oleh Allah

Gambar 2. Tampilan Content Pembelajaran pada TV Sekolah 


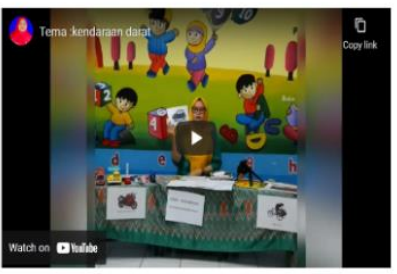

Macam Macam Kendaraar

Gambar 3. Tampilan Content Pembelajaran pada TV Sekolah

\section{SIMPULAN DAN SARAN}

\section{A. Simpulan}

Peningkatan kreativitas guru sangat terlihat jelas dalam proses penyiapan TV Sekolah, melalui tahapan perencanaan kegiatan sampai kepada tahap telah tayang di TV Sekolah. Kreativitas Guru akan terus meningkat seiring dengan semakin berkembangnya TV Sekolah dalam sebuah lembaga, karena tuntutan dari peserta didik untuk mendapatkan kegiatan pembelajaran yang dapat di akses melalui TV Sekolah.

\section{B. Saran}

Saran untuk penulis adalah bagaimana penulis dapat terus mengembangkan penelitian kreativitas guru dalam memanfaatkan TV sekolah ini secara mendalam.

\section{DAFTAR RUJUKAN}

Bandi harpeni dkk, ,Kreativitas guru dalam memanfaatkan Media berbasis IT ditinjau dari gaya belajar siswa, https://jurnal.iainbone.ac.id/index.php/algurfah/index 15

Direktorat Sekolah Dasar : Pembelajaran jarak jauh bias jadi model pendidikan masa depan

http://ditpsd.kemdikbud.go.id/artikel/det ail/pembelajaran-jarak-jauh-pjj-bisa-jadimodel-pendidikan-masa-depan
Dra. Widarmi D. Wijana, M.M,Konsep Dasar Pendidikan Anak Usia Dini https://pustaka.ut.ac.id/lib/wpcontent/uploads/pdfmk/PAUD4409M1.pdf

Ifat latifah,Sri Watini, (2022) ,PeranTV Sekolah sebagai alternative media pembelajaran jarak jauh (PJJ) di TKIT Al Hikmah ,http://jiip.stkipyapisdompu.ac.id/jiip/ind ex.php/JIIP/issue/archive

Punut Setiono, Kreativitas Guru dalam media pembelajaran di kelas V sekolah Dasar, https://online-

journal.unja.ac.id/gentala/issue/view/820

Purwanto, A., Pramono, R., Asbari, M., Santoso, P. B., Wijayanti, L. M., Choi, C. H., \& Putri, R. S. (2020). Studi Eksploratif Dampak Pandemi COVID-19 Terhadap Proses Pembelajaran Online di Sekolah Dasar. EduPsyCouns: Journal of Education, Psychology and Counseling, 2(1), 1-12. https://ummaspul.ejournal.id/Edupsycou ns/article/vi ew/3

Ramli, M. (2005). Pendampingan Perkembangan Anak Usia Dini. Jakarta: Dirjen Dikti PPLPTK Departemen P dan K

Siti Maymunah, Sri Watini,(2021) Pemanfaatan media video dalam pembelajaran anak usia dini dimasa pandemic covid-19,Jurnal Pendidikan Tambusai, Vol. 5 No. 2 (2021):2021

Sri watini (2021), Implementasi model pembelajaran,

https://obsesi.or.id/index.php/obsesi/arti cle/view/190/pdf

Sri Watini, (2021), TV Sekolah; https://tvsekolah.id/tentangkami 